\title{
Development of polymorphic microsatellite markers for Dioscorea zingiberensis and cross-amplification in other Dioscorea species
}

\author{
Q.-Q. Yan, X.-Q. Sun, J.-L. Guo, Y.-Y. Hang and M.-M. Li \\ Jiangsu Provincial Key Laboratory for Plant Ex Situ Conservation, \\ Institute of Botany, Jiangsu Province and Chinese Academy of Sciences, \\ Nanjing, China \\ Corresponding authors: M.-M. Li / Y.-Y. Hang \\ E-mail: limm001@163.com / hangyueyu@gmail.com
}

Genet. Mol. Res. 12 (3): 3788-3792 (2013)

Received January 20, 2013

Accepted August 22, 2013

Published September 19, 2013

DOI http://dx.doi.org/10.4238/2013.September.19.10

\begin{abstract}
Dioscorea zingiberensis C.H. Wright (Dioscoreaceae) is an endemic species in central and southwestern China. In order to study the genetic diversity and population structure of this species, 19 novel polymorphic microsatellite loci were developed using a dual-suppression PCR technique. The number of alleles per locus ranged from 3 to 21, with an average of 9.53. All the markers showed high transferability in cross-species amplification in other species of sect. Stenophora.
\end{abstract}

Key words: Dioscorea zingiberensis; Dioscorea sect. Stenophora; Microsatellite; Transferability 


\section{INTRODUCTION}

Dioscorea zingiberensis C.H. Wright (Dioscoreaceae) is an endemic species in central and southwestern China (Ting and Gilbert, 2000). As the main resource of diosgenin, it is considered to be an extremely important traditional medicine (Ting et al., 1985). The wild populations have declined extensively as a result of overexploitation. In order to better understand the genetic diversity and population structure of $D$. zingiberensis, microsatellite loci were isolated using a dual-suppression PCR technique (Lian et al., 2006), and the cross-species amplification was tested in 10 other species of sect. Stenophora.

\section{MATERIAL AND METHODS}

Two populations of D. zingiberensis were collected in Mt. Wudang and Ankang, China. Ten species of sect. Stenophora were collected for testing the cross-species amplification. Voucher specimens were deposited in the Herbarium of Institute of Botany, Jiangsu Province and Chinese Academy of Sciences (NAS) (Table 1).

\begin{tabular}{lll} 
Table 1. Material information. & & \\
\hline Species & Location & Voucher \\
\hline Dioscorea zingiberensis C.H. Wright & Ankang, Shaanxi & 0648768 \\
& Mt. Wudang, Hubei & 0648769 \\
D. collettii var. hypoglauca (Palibin) C. Pei \& C.T. Ting & Hengshan, Hu'nan & 0648579 \\
& Yandangshan, Zhejiang & 200909061 \\
D. nipponica ssp rosthornii (Prain \& Burkill) C.T. Ting & Liushan, Gansu \\
D. nipponica ssp nipponica Makino & Menghai, Yunnan \\
& Guangfo, Shaanxi & 0648571 \\
D. futschauensis Uline ex R. Knuth & Qingyunshan, Fujian \\
D. banzhuana C. Pei \& C.T. Ting & Mengzi, Yunnan \\
D. simulans Prain \& Burkill & Guilin, Guangxi \\
D. spongiosa J.Q. Xi, M. Mizuno \& W.L. Zhao & Hengshan, Hu'nan \\
D. deltoidea Wallich ex Grisebach & Deqin, Yunnan \\
D. sinoparviflora C.T. Ting, M.G. Gilbert \& Turland & Honghe, Yunnan \\
\hline
\end{tabular}

Genomic DNA was extracted from fresh leaves of D. zingiberensis using a modified hexadecyltrimethylammonium bromide (CTAB) method (Doyle, 1991). One individual from the Ankang population was used to generate microsatellite sequences. The genomic DNA samples were digested with the $A f a$ I restriction enzyme (TaKaRa), and restricted fragments were ligated with an adaptor (upper-lian: 5'-GTA ATA CGA CTC ACT ATA GGG CAC GCG TGG TCG ACG GCC CGG GCT GGT-3'; lower-lian: 5'-ACC AGC CC- $\left.\mathrm{NH}_{2}-3^{\prime}\right)$ by use of T4 ligase (TaKaRa). Fragments were amplified using compound single sequence repeat $(\mathrm{SSR})$ primers $(\mathrm{AC})_{6},(\mathrm{AG})_{5}$, or $(\mathrm{TC})_{6}(\mathrm{AC})_{5}$ and an adaptor primer, $\mathrm{AP}_{2}$ (5'-CTA TAG GGC ACG CGT GGT-3'). PCR amplification was performed in a final volume of $50 \mu \mathrm{L}$, consisting of 25 to $50 \mathrm{ng}$ DNA, 1X PCR buffer (containing 
$\mathrm{Mg}^{2+}$ ), $0.2 \mathrm{mM}$ dNTPs, $0.5 \mu \mathrm{M}$ compound SSR primer and $\mathrm{AP}_{2}$, and $0.5 \mathrm{U}$ Ex Taq polymerase (TaKaRa). The PCR amplification conditions were as follows: an initial denaturation at $94^{\circ} \mathrm{C}$ for $9 \mathrm{~min}$, annealing at $62^{\circ} \mathrm{C}$ for $30 \mathrm{~s}$, and extension at $72^{\circ} \mathrm{C}$ for $1 \mathrm{~min} ; 5$ cycles of denaturation at $94^{\circ} \mathrm{C}$ for $30 \mathrm{~s}, 62^{\circ} \mathrm{C}$ for $30 \mathrm{~s}$, and $72^{\circ} \mathrm{C}$ for $1 \mathrm{~min} ; 35$ cycles of denaturation at $94^{\circ} \mathrm{C}$ for $30 \mathrm{~s}$, annealing at $60^{\circ} \mathrm{C}$ for $30 \mathrm{~s}$, and $72^{\circ} \mathrm{C}$ for $1 \mathrm{~min}$; and a final cycle of denaturation at $94^{\circ} \mathrm{C}$ for $30 \mathrm{~s}, 60^{\circ} \mathrm{C}$ for $30 \mathrm{~s}$, and $72^{\circ} \mathrm{C}$ for $5 \mathrm{~min}$. The amplified fragments were purified using a DNA gel product recycling kit. Then, the purified fragments were ligated into a pMD-19T vector (TaKaRa). The plasmids were transformed into competent Escherichia coli DH5 $\alpha$ cells (TaKaRa), and the transformed cells were cultivated on agar medium containing $100 \mu \mathrm{g} / \mu \mathrm{L}$ Ampicillinum natricum. The cloned fragments were amplified from the plasmid DNA of positive clones using the M13-47/ RV-M universal primers (M13-47: 5'-CGC CAG GGT TTT CCC AGT CAC GAC-3'; RV-M: 5'-GAG CGG ATA ACA ATT TCA CAC AGG-3'). Positive clones were obtained and sequenced on an ABI Prism 3730 automated DNA sequencer (Applied Biosystems, Foster City, CA, USA). Sequences were edited by the Sequencher 4.5 (Gene Coding, Ann Arbor, MI, USA). For each fragment containing compound SSR sequences at one end, a specific primer was designed from the sequence flanking the compound SSR, using Primer Premier 5 (Clarke and Gorley, 2001).

To examine the effectiveness and polymorphism of the primers, 26 individuals from Mt. Wudang and 22 individuals from Ankang were collected, respectively. The compound SSR primers were labeled with fluorescence dyes (6-FAM or HEX). The amplified products were analyzed by fluorescence capillary electrophoresis on an ABI Prism 3730 automated DNA sequencer (Applied Biosystems), and the data were compiled and scored using GeneMaker 1.95 (Soft-Genetics, State College, PA, USA). Cervus 2.0 (Kalinowski et al., 2007) was used to calculate the $N_{\mathrm{A}}$ (number of alleles per locus), $H_{\mathrm{O}}$ (observed heterozygosity), and $H_{\mathrm{E}}$ (expected heterozygosity). Genepop (http://genepop.curtin.edu.au/) was employed to test the Hardy-Weinberg equilibrium and linkage disequilibria (LD) between pairs of loci with Bonferroni correction for multiple testing (Rice, 1989). Cross-amplifications were done to test the transferability of the 19 loci in 10 species of sect. Stenophora, and the amplified fragments were checked by $1.5 \%$ agarose gel electrophoresis.

\section{RESULTS}

Nineteen microsatellite markers were isolated from D. zingiberensis (Table 2). The $N_{\mathrm{A}}$ per locus ranged from 3 to 21 , with an average of 9.53 alleles per locus. The $H_{\mathrm{O}}$ values ranged from 0.125 to 0.708 , with an average of 0.328 , whereas the $H_{\mathrm{E}}$ values ranged from 0.511 to 0.940 , with an average of 0.750 . The polymorphism information content of the 19 microsatellite loci ranged from 0.486 to 0.926 , with an average of 0.713 . None of microsatellite loci deviated significantly from Hardy-Weinberg equilibrium $(\mathrm{P}<0.01)$. The pairwise LD between the 19 pairs of loci was not significance $(\mathrm{P}<0.001)$. Cross-amplifications results showed that the novel microsatellite loci developed had high transferability in sect. Stenophora (Table 3). 
Table 2. Characteristics of 19 microsatellite loci developed for Dioscorea zingiberensis.

\begin{tabular}{|c|c|c|c|c|c|c|c|c|c|}
\hline Locus & Primer sequence $\left(5^{\prime}-3^{\prime}\right)$ & Repeat motif & $\mathrm{Ta}\left({ }^{\circ} \mathrm{C}\right)$ & $\begin{array}{l}\text { Size } \\
\text { (bp) }\end{array}$ & $N_{\mathrm{A}}$ & $H_{\mathrm{O}}$ & $H_{\mathrm{E}}$ & PIC & $\begin{array}{l}\text { GenBank } \\
\text { accession No. }\end{array}$ \\
\hline DzSSR1 & $\begin{array}{l}\text { F: (TC) })_{6}(\mathrm{AC})_{5} \\
\text { R: ATTTTTAATCTTTTTTTCCTCC } \\
\text { F: }(A C)(A G)\end{array}$ & $(\mathrm{TC})_{6}(\mathrm{AC})_{12} \mathrm{~A}(\mathrm{AAAC})_{7}$ & 45.2 & 96 & 7 & 0.333 & 0.511 & 0.486 & JX235677 \\
\hline DzSSR3 & $\begin{array}{l}\text { F: (AC) })_{6}(\mathrm{AG})_{5} \\
\text { R: TAGGAATCGGCATTTGAGAGCT } \\
\text { F: (AC) })_{6}(\mathrm{AG})_{5}\end{array}$ & $(\mathrm{AC})_{6}(\mathrm{AG})_{19}$ & 48.6 & 160 & 9 & 0.292 & 0.826 & 0.795 & JX235678 \\
\hline DzSSR4 & $\begin{array}{l}\text { R: TCAAAAATACTAACAAAACCCT } \\
\text { F: }(\mathrm{AC})_{6}(\mathrm{AG})_{5}\end{array}$ & $(\mathrm{AC})_{6}(\mathrm{AG})_{10}$ & 46 & 78 & 15 & 0.438 & 0.907 & 0.890 & JX235679 \\
\hline DzSSR5 & $\begin{array}{l}\text { R: TCAGAAGGTCATCGTCATCA } \\
\text { F: }\left(\text { AC) }{ }_{6}(\mathrm{AG})_{5}\right.\end{array}$ & $(\mathrm{AC})_{6}(\mathrm{AG})_{10}$ & 50 & 152 & 7 & 0.208 & 0.719 & 0.664 & JX235680 \\
\hline DzSSR6 & $\begin{array}{l}\text { R: AAAGACTTCATTCCAG } \\
\text { F: }(\text { AC })_{6}(\mathrm{AG})_{5}\end{array}$ & $(\mathrm{AC})_{6}(\mathrm{AG})_{22}$ & 49.1 & 160 & 21 & 0.708 & 0.940 & 0.926 & JX235681 \\
\hline DzSSR7 & $\begin{array}{l}\text { R: AACAGAAGGGCAAGAACC } \\
\text { F: }(\text { AC) })_{6}(\mathrm{AG})_{5} \\
\text { R: TTCCACCACAACCCGAC }\end{array}$ & $(\mathrm{AC})_{6}(\mathrm{AG})_{5}$ & 50.9 & 136 & 7 & 0.271 & 0.708 & 0.654 & JX235682 \\
\hline DzSSR8 & $\begin{array}{l}\text { F: (AC) })_{6}(\mathrm{AG})_{5} \\
\text { R: ATGAAACAAGAAAGAAACAAAG }\end{array}$ & $(\mathrm{AC})_{6}(\mathrm{AG})_{20}$ & 54 & 296 & 8 & 0.417 & 0.761 & 0.729 & JX235684 \\
\hline $\begin{array}{l}\text { DzSSR9 } \\
\text { DzSSR10 }\end{array}$ & $\begin{array}{l}\text { F: }(A C)_{6}(\mathrm{AG})_{5} \\
\text { R: CAAAAGACAGAGAAGCACATAC } \\
\text { F: }(\mathrm{AC})_{6}(\mathrm{AG})_{5}\end{array}$ & $(\mathrm{AC})_{6}(\mathrm{AG})_{6}$ & 50.1 & 188 & 12 & .313 & 0.856 & 0.831 & JX235685 \\
\hline DzSSR11 & $\begin{array}{l}\text { R: TCCAGATAATAGGTAGGAACATA } \\
\text { F: (AC) }(\text { AG) })_{5} \\
\text { R } \cdot \text { GGCTGGTC }\end{array}$ & $(\mathrm{AC})_{6}(\mathrm{AG})_{5}$ & 47.2 & 163 & 8 & 0.458 & 0.759 & 0.721 & JX235686 \\
\hline DzSSR12 & $\begin{array}{l}\text { R: GGCTGGTACTTTGCTTGC } \\
\text { F: }(\text { AC) })_{6}(\text { AG) } \\
\text { R: TGGATGCCTTGAGATGAGG }\end{array}$ & $\begin{array}{l}(\mathrm{AC})_{6}(\mathrm{AG})_{6} \\
(\mathrm{AC})_{6}(\mathrm{AG})_{15}\end{array}$ & 49.1 & 150 & 11 & 0.313 & 0.768 & 0.739 & $\begin{array}{l}\text { JX235687 } \\
\text { JX235688 }\end{array}$ \\
\hline DzSSR13 & $\begin{array}{l}\text { F: }(A C)_{6}(A G)_{5} \\
\text { R: TTCACCACCAACAGCATT } \\
\text { F: }(A C)(A G) .\end{array}$ & $(\mathrm{AC})_{6}(\mathrm{AG})_{13}$ & $\$ 7.7$ & 107 & 3 & 0.333 & 0.575 & 0.477 & JX235689 \\
\hline DzSSR15 & $\begin{array}{l}\text { AGGGACCTCAACT } \\
y_{5}\end{array}$ & $(\mathrm{AC})_{6}(\mathrm{AG})_{11}$ & 46.8 & 87 & 8 & 0.271 & 0.785 & 0.747 & JX235690 \\
\hline DzSSR16 & $\begin{array}{l}\text { R: CTTTGCTTGCTTCTTCATC } \\
\text { F: (AC) })_{6}(\mathrm{AG})_{5} \\
\text { R: CATAGGTTTATTCTTGGTGC }\end{array}$ & $(\mathrm{AC})_{6}(\mathrm{AG})_{5}$ & 47.5 & 140 & 7 & 0.125 & 0.589 & 0.543 & $\begin{array}{l}J X 235691 \\
\text { JX235692 }\end{array}$ \\
\hline DzSSR17 & $\begin{array}{l}\text { F: }(\mathrm{AC})_{6}(\mathrm{AG})_{5} \\
\text { R: AAAATACTAACAAAACCCTACAC } \\
\text { F: }(\mathrm{AC})_{6}(\mathrm{AG})_{5}\end{array}$ & $(\mathrm{AC})_{6}(\mathrm{AG})_{19}$ & 47.1 & 93 & 18 & 0.146 & 0.906 & 0.889 & JX235693 \\
\hline DzSSR19 & IGTATGGAACAC & $(\mathrm{AC})_{6}(\mathrm{AG})_{14}$ & 46.8 & 192 & 8 & 0.438 & 0.786 & 0.754 & JX235694 \\
\hline Mean & ITACCCACAGC & $(\mathrm{AC})_{6} \mathrm{C}$ & 51 & 97 & $\begin{array}{l}8 \\
9.53\end{array}$ & $\begin{array}{l}0.500 \\
0.328\end{array}$ & $\begin{array}{l}0.793 \\
0.750\end{array}$ & $\begin{array}{l}0.759 \\
0.713\end{array}$ & JX235695 \\
\hline
\end{tabular}

Ta $=$ optional annealing temperature; $N_{\mathrm{A}}=$ number of alleles; $H_{\mathrm{O}}=$ observed heterozygosity; $H_{\mathrm{E}}=$ expected heterozygosity; $\mathrm{PIC}=$ polymorphic information content.

Table 3. Results of cross-species amplification in 10 species in Dioscorea sect. Stenophora.

\begin{tabular}{|c|c|c|c|c|c|c|c|c|c|c|c|c|c|c|c|c|c|c|c|c|}
\hline \multirow[t]{2}{*}{ Species } & \multirow[t]{2}{*}{ Voucher } & \multicolumn{19}{|c|}{ SSR primer } \\
\hline & & 1 & 2 & 3 & 4 & 5 & 6 & 7 & 8 & 9 & 10 & 11 & 12 & 13 & 14 & 15 & 16 & 17 & 18 & 19 \\
\hline D. collettii var. hypoglauca & 0648579 & + & - & + & + & - & - & - & - & - & 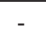 & - & + & + & + & - & - & + & - & - \\
\hline D. collettii var. hypoglauca & 200909061 & + & - & + & + & - & 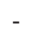 & - & - & - & - & . & + & + & + & - & - & + & - & - \\
\hline D. nipponica $\mathrm{ssp}$ rosthornii & 0648571 & + & - & + & + & 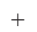 & 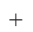 & + & + & + & + & - & + & + & + & + & + & + & - & - \\
\hline D. nipponica & 0648 & + & + & + & + & + & + & + & + & + & + & - & + & + & + & + & r & + & + & + \\
\hline D. nipponica & 00909011 & + & + & + & + & + & + & + & + & + & + & + & + & + & + & + & + & + & + & + \\
\hline D. futschauensis & 0648580 & + & - & + & + & + & + & + & + & + & + & - & - & - & - & - & + & + & - & - \\
\hline D. banzhuana & 0648582 & + & - & + & + & + & + & + & + & + & + & - & + & + & + & - & + & + & - & - \\
\hline D. simulans & 0648583 & + & - & + & + & + & + & - & + & + & - & - & + & + & + & + & + & + & + & + \\
\hline D. spongiosa & 0648581 & + & - & + & + & + & + & + & + & + & + & - & + & - & + & - & + & - & - & - \\
\hline D. deltoidea & 0648575 & + & - & + & + & + & + & + & + & + & + & + & + & + & + & + & + & + & + & + \\
\hline D. sinoparviflora & 0648574 & + & + & + & + & + & + & + & + & + & + & + & + & + & + & + & + & + & + & + \\
\hline
\end{tabular}

$(+)=$ successful amplification with a size similar to that of Dioscorea zingiberensis; $(-)=$ no amplification. 


\section{DISCUSSION}

The development of microsatellite markers for D. zingiberensis is essential for ongoing research on genetic diversity and population structure. The information generated is of great importance for the conservation of the genetic variability of this species, as well as other species in sect. Stenophora.

\section{ACKNOWLEDGMENTS}

Research supported by a grant of the Main Direction Program of Knowledge Innovation of the Chinese Academy of Sciences (Grant \#KSCX2-YW-Z-028). The authors thank Mr. Wei Zhao and Mr. Min Zhao for their kind help in the field trip.

\section{REFERENCES}

Clarke KR and Gorley RN (2001). Primer v5: User Manual/Tutorial. Primer-E Ltd., Plymouth.

Doyle JJ (1991). DNA Protocols for Plants. In: Molecular Techniques in Taxonomy (Hewitt GM, Johnston AWB and Young JPW, eds.). Springer-Verlag, Berlin, 283-293.

Kalinowski ST, Taper ML and Marshall TC (2007). Revising how the computer program CERVUS accommodates genotyping error increases success in paternity assignment. Mol. Ecol. 16: 1099-1106.

Lian CL, Abdul WM, Geng Q, Shimatani K, et al. (2006). An improved technique for isolating codominant compound microsatellite markers. J. Plant Res. 119: 415-417.

Rice WR (1989). Analyzing tables of statistical tests. Evolution 43: 223-225.

Ting CT, Chang MC and Ling PP (1985). Flora of China. Science Press, Beijing.

Ting CT and Gilbert MG (2000). Dioscorea Linnaeus. In: Flora of China (Wu ZY and Raven PH, eds.). Science Press, Beijing, 276-296. 